\title{
Land Conflict in Kenya: A Comprehensive Overview of Literature
}

Philip Onguny and Taylor Gillies

\section{Q OpenEdition}

Electronic version

URL: https://journals.openedition.org/eastafrica/879

ISSN: 2790-1076

Publisher

IFRA - Institut Français de Recherche en Afrique

\section{Electronic reference}

Philip Onguny and Taylor Gillies, "Land Conflict in Kenya: A Comprehensive Overview of Literature", Les Cahiers d'Afrique de l'Est / The East African Review [Online], 53 | 2019, Online since 06 January 2020, connection on 09 December 2021. URL: http://journals.openedition.org/eastafrica/879

This text was automatically generated on 9 December 2021.

Les Cahiers d'Afrique de l'Est / The East African Review 


\title{
Land Conflict in Kenya: A Comprehensive Overview of Literature
}

\author{
Philip Onguny and Taylor Gillies
}

\section{Introduction}

1 Although the challenges of land conflict in Africa are not new, there have been polarized debates on how to address the varying land claims, most of which have revolved around people-centred reforms and market-centred land regimes (Alden and Anseeuw 2010). Because land occupies a central role in many African livelihoods, the growing scarcity of land is often framed within the contexts of "global land rush" (Dell'Angelo et al. 2017; Scoones et al. 2019) and has played a particular role in the politicization of narratives about land use and land ownership in Africa. In addition to being a valuable resource for many, people's identity and sense of belonging are intrinsically intertwined with land discourse (Klaus 2017; Watson 2019). This makes land a symbolic entity with varying interests, sometimes irreconcilable or nonnegotiable. The difficulty addressing competing land claims in Africa may explain why the African Union Commission (AUC), the UN Economic Commission for Africa (ECA), and the African Development Bank (AfDB) jointly proposed the ambitious Framework and Guidelines on Land Policy in Africa in 2010 to guide policy discussions on land regimes in Africa.

2 Whereas the practical implications of this document are yet to be determined, there have been increased efforts to reform land laws and policies in many African countries. In West Africa, for instance, Ghana, Côte d'Ivoire, Niger, and Nigeria have seen significant shifts in their land policies over the past decade (Boone 2017; Fenske 2011; Pritchard 2016). Similarly, southern African states such as Zimbabwe, South Africa and, to some extent, Botswana, are all experiencing pressure to review their land policies, some of which have taken anti-settler narratives (Kalabamu 2019). Meanwhile, political 


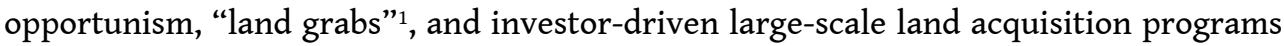
are believed to drive most of the discussions about land rules in many East African countries such as Kenya and Ethiopia (Klaus, 2017).

With increasing contradictions associated with standardized land policies, some have warned against the pitfalls of not considering a context-specific approach to land governance regimes. Drawing on Land Governance Assessment Framework (LGAF), scholars such as Deininger, Hilhorst and Songwe (2014: 86) conducted a comparative study in ten African countries showing that "although the importance of land governance for Africa's agricultural and broader development has long been acknowledged, the extent to which it was reflected in country strategies, addressed effectively by specific programs, or monitored over time was limited." Meanwhile, other studies have shown that existing structures of authority have not been able to meaningfully "define [...] who belongs, or who claims to belong, to these territories" (Rutherford 2017: 235). This is particularly true because, as Nuhu (2019:1) reminds us, land governance in Africa's peri-urban is "shaped by divergent or complimentary roles of actors emanating from their authority, power and interest which create a complex relationship affecting land governance process." This is attributed to the proliferation of third-party actors who increasingly challenge the monopoly of state over land governance (Gwaleba and Masum 2018).

Whether regarded as a problem of belonging, rent collection, or rights, there is a sizable amount of literature from various disciplines seeking to understand land questions in Africa more generally. Nonetheless, land politics in Kenya are of particular interest for several reasons. As Boone (2012: 77) rightly points out, "unlike land politics in many African countries, which often centers on the use and abuse of ostensibly customary authority... the major land disputes in much of Kenya are focused on how the power of the central state has been used to allocate land." It is within this logic that the present article reviews and discusses the dominant scholarly narratives on land claims in Kenya and how they address land conflict. The objective is to understand what the dominant lines of argument are with respect to land conflict, and to identify the main actors involved in land conflict. This literature review is part of a larger study seeking to develop a comprehensive typology of frames for land conflict and ethnopolitical violence in Kenya.

5 The contribution of this literature review to ongoing debates on land conflicts in Kenya is twofold. First, it provides a means to sort through the fragmented literature on conflict over land by identifying the common areas around which land claims are grounded. As such, it offers sparks for theoretical advancements and/or empirically grounded analytical work. Second, although it is virtually impossible to formulate an all-encompassing understanding of land conflicts across Africa, this literature review contributes to the ongoing debates on how, when, why and by whom land narratives are incentivized to generate conflict over land across time and space.

6 The article begins by examining the dominant lines of inquiry into land questions in Africa more generally, before focusing on how, why and when conflicts over land are incentivized in Kenya. The conclusion identifies potential gaps in the literature on land questions in Kenya and directions for future research. The overall objective is to uncover the narratives of land conflicts in Africa and narrow the focus to the Kenyan context. 


\section{Dominant Lines of Inquiry into Land Questions in Africa}

7 Several lines of inquiry have been provided as potential explanations for land conflict in Africa. One such explanation associates land problems within colonial legacy, emphasizing pre-independence (re)distributive land policies (Austin 2010; Blanton, Mason, and Athow 2001). The core argument here is that, if land conflicts continue to persist in Africa, it is largely because of the restructuring processes that accompanied the social, political and economic policies, of which land governance plays a central role.

8 A primary example of this is the continued use of state borders created by colonial occupiers in an effort to administer territories without taking into account previously existing land traditions (Boone 2012; Klaus 2017). Consistent with this perspective, Yamano and Deininger (2005: 1) also observe that "in many African countries, formal institutions for land administration were often simply superimposed on traditional structures without a clear delineation of responsibilities and competencies, implying that they lack both outreach and social legitimacy." In essence, such practices are believed to have contained communities to specific geographic areas (Khadiagala 2010). of course, some have contended that "Africa's history does not begin with colonialism and its legacy" and that political organization in Africa, such as kingdoms, influenced varying forms of political violence before colonial occupation (Besley and ReynalQuerol 2014: 2). Since land conflicts existed before colonial occupation (Keller 2014), the exact foundations for the ongoing land problems requires close examinations of local contexts and shifts in property rights that took place during colonization (Haugerud 1989; Kanogo 1987; Okoth-Ogendo 1989).

9 Another dominant view on land conflict in Africa situates competing land claims within the context of growing environmental concerns. Here, the literature on conservation, however polarized, invokes the urgent need to address human-nature relations in order to increase the sustainability of natural resources (Baynham-Herd et al. 2018; Redpath et al. 2013). Agriculture and urbanisation are both primary topics of discussion since they both represent Africa's primary economy. Africa's overall GDP is approximately $17 \%$ based in agriculture (United Nations Economic Commission for Africa, 2019), whereas its urbanisation projects are exemplary of global modernization processes. For countries that depend so heavily on agriculture for their livelihoods, the dynamics of climate change steadily exacerbate these problems, especially in relation to land arability, erosion, infertility, and water drought (Ani 2013). Socioeconomic fallout continues as a domino effect, with diminished levels of potable water for sanitation and health, economic instability from lack of agricultural resources, as well as annual food shortages (Ibid.). At the international level, climate change further aggravates humanitarian concerns such as higher rates of environmental refugees, leading to increased fragility and eventual threats made against state sovereignty (Environmental Justice Foundation 2014).

Other studies on land conflicts specific to Africa have also centred on the politics of natural resource extraction and unbalanced rent sharing between the elite and ordinary citizens (Janus 2012). At the core of these studies is the assumption that a handful of corrupt rent-seeking elites play a central role in determining who enjoys most of the rents from natural resources (Boone 1990; Ovadia 2013). This duality-based 
relationship between elites and citizens is hierarchal and exists as a verticaldependence system (Rigon 2014), meaning citizens do not have the power to question the imbalances of sharing natural resources. For the most part, these arguments subscribe into the "resource trap" and "resource curse" themes, establishing the connections between natural resource abundance or scarcity and the likelihood of violent conflict over land (Carmignani and Chowdhury 2010; Frynas, Wood, and Hinks 2017). Whereas the elites keep the predominance of natural resources under their control to maintain power, these arguments suggest that violence is more likely to erupt amongst citizens who have less access to such resources or more to gain from them.

11 Increasingly, however, a growing number of scholars have shifted their attention to the "sons of the soil" literature to highlight the cultural dimensions of conflict, and how they inform people's identity and sense of belonging with regard to land use, access or ownership (Boone 2017; Mitchell 2018). Here, land is negotiated as a form of identity, often tied to lines of ancestry (Keller 2014) that is comparable to modern understandings of citizenship. There is an emotional context entrenched within the historical significance of land and how it is attributed to individuals who are born into a shared community (Lonsdale 2008; Boone 2012; Mitchell 2018). When this affective connection is threatened-through land grabbing, climate change, political take-over, etc. - , then the threat against that shared community's identity of land, autonomy and/or security is met with popular outrage (Boone 1990; Dunn 2009; Klopp 2000).

These arguments, although not exhaustive, provide a window into understanding the broad questions surrounding land claims in Africa and related conflict. The next sections focus on the particularities of land problems in Kenya specifically, and how they have informed land conflicts over time and space.

\section{Laying the Terrain: Political History of Land Use Patterns in Kenya}

Land questions in Kenya are complex, multilayered, and highly politicised. Understanding the dynamics of land problems in Kenya therefore invites discussion on the colonial and post-colonial political contexts that have informed the structure of property rights across time and space, and an understanding of how national elites have used land and land access rights to influence the narratives on land ownership and control land institutions.

In the pre-colonial era, land rights were mainly managed as Commons ${ }^{2}$. That is, "by a social hierarchy organized in the form of an inverted pyramid with the tip representing the family, the middle as the clan and lineage, and the base, the community" (OkothOgendo 2002: 108). For the Kenyan Law Professor Okoth-Ogendo, such structures allowed societies to govern their lands based on collective values and principles, taking into consideration both the current and future needs as well as the responsibility to protect group's territory. In essence, the pre-colonial land management depended on subsistence agriculture and pastoralism systems (Haugerud 1989). Further, "the pastoralists also had better-organized warriors to extend and protect their territories... [even though] both the agrarian and pastoral societies left large tracts of land for resource management purposes..." (Wamicha and Mwanje 2000: 20). In short, managing land rights as part of the Commons meant that such rights "were not susceptible to 
inter vivos transfers outside each level of social organization even though latitudinal exchange of function-specific rights was and remains common" (Okoth-Ogendo 2002: 108).

During colonization, land in Kenya considered unoccupied by the British settlers was declared Crown land, i.e. land on which the Commissioner acted on behalf of the Queen of England (Crown Lands Ordinace of 1902), as well as Trust Land (Kanogo 1987; OkothOgendo 1989) ${ }^{3}$. Access to and control over land thus shifted from earlier forms of social ownership to "market-oriented" or private ownership systems. As Haugerud explains, "nowhere... [did] the Kenyan state [have] the capacity to keep the land registers up to date..." (Haugerud 1989: 61), which is why the "objectives were to replace the uncertainty of customary tenure with a system of individual land titles registered and guaranteed by the state; and to expand cash crop production, improve agricultural techniques and encourage agricultural investment once fragmented holdings were consolidated into units of economic size once registered titles could be used as security for agricultural loans" (Ibid.: 63). This view is not shared by all Kenyan scholars, such as Okoth-Ogendo, who argue that the introduction of concepts such as "ownership" by the colonial regime masked other forms of property ownership that existed, and that the absence of land registries per se did not imply absence of a land regime. He writes: "the view of property that was taken was always loaded with the values of Western materialism... [and that] it was assumed, for example, that tenure arrangements were always completed by a bond, called title, which tied individuals or combinations thereof to some delineated portions of the physical solum in a way that conferred both jurisdiction and exclusive control" (Okoth-Ogendo 1989: 7).

What is certain, however, is that the modern colonial state... "[did] the most to supersede customary land rights and to assume the role of "landlord" to peasant producers in some of Africa's most developed and highly commercialized agricultural economies" (Ibid.: 1312). In fact, "by 1939, most of the remaining high potential land remained as crown land under the direct control of the governor, and native areas, recategorized as 'trust lands', were under the control of land boards accountable to the governor" (Klopp 2000: 15). Although some of the new land tenure practices were aimed at containing dissent from pressure groups such as the Mau Mau anticolonial struggle movement (Kanogo 1987), land rights shifted from "traditional" institutions of ownership to private ownership, thus providing individuals and groups of individuals with powers for exclusive appropriation and/or control over land and related resources (Boone 2011; Haugerud 1989; Okoth-Ogendo 1989).

The post-colonial era mainly saw the "elite capture" of property rights. The land that had been occupied by white settlers, particularly the British, were acquired by the postcolonial regime of Jomo Kenyatta (1963-1978) and eventually sold to national elites who gained control of the property ownership structure (Kanyinga 1998; Okoth-Ogendo 1989). The trend was continued under Daniel arap Moi's regime (1978-2002), known for distributing public lands for political purposes (Greiner 2013; Klopp 2001). Land regimes therefore became connected to post-colonial national politics in Kenya, with successive governments becoming reluctant to transform land regimes in a manner that would address irregular land allocations over the years. This is because land rights have become instruments of structuring political relationships, connecting elite "landlords" in various regions to the central state (Greiner 2013; Onoma 2010). This link of interdependency is captured by Boone's observation, suggesting that "the direct tie 
between central state agents and land users often persisted over time through relations of indebtedness, patron clientage, and/or access to land in the absence of official titles... [and that] these past and ongoing relationships provided a historical and political (if not legal) basis for Rift Valley politicians' claims to prerogative over land allocation in the present and near future" (Boone 2011: 1313). This may explain why national elites seeking electoral support repeatedly manipulate land-tenure relationships to influence land-related grievances in some parts of the country such as the Rift Valley, as witnessed during the 1992, 1997, and 2007 elections (Bates 2005; Boone 2011; Klopp 2001).

In short, post-colonial land-tenure regimes have been manipulated by varying national elites to influence ethnic conflicts (Médard 1996; Oucho 2002), to illegally distribute public lands such as forestland for personal interests and political gains (Klopp 2001; Ndung'u Report 2004), and to stifle the operations of land institutions (Okoth-Ogendo 2002; Onoma 2010). And, as Klopp (2000: 15) puts it, "one might say that Kenya was founded by successive acts of land grabbing, and hence, land grabbing is as old as Kenya itself, if not older."

\section{Competing Narratives About Land Conflict in Kenya}

Pending the political history provided above, this paper identifies and discusses four dominant explanations in the literature that connects competing land claims to landrelated conflict and/or violence in Kenya. This includes colonial legacy and historicity, environmental concerns and climate change, unbalanced natural resource rent sharing, and the "sons of the soil" argument. These explanations are considered to be communicative and commentary to one another.

\section{Colonial Legacy, Historicity, and Land Conflict}

The literature on land conflict specific to Kenya identifies colonial legacy as one of the primary reasons generating land-related grievances. In addition to altering land tenure regimes, the affinity colonists had for choosing favorites amongst the African ethnicities, showing them greater privileges, including land rights, created a foundation for violence over land in areas such as Rift Valley and Central regions of Kenya (Boone 2011; Mbah 2016). As Haugerud puts it, "the initial phase of defining and adjudicating clan and individual rights, particular parcels of land [during colonization] involved both clan elders and appointed officials such as assistant chiefs and chiefs" (Haugerud 1989: 63). In areas where there were no chiefs, Berman (1990) observes that chiefs were "created" to facilitate territorial administration. These arrangements had a profound impact on how territorial boundaries were drawn, including the rights that were associated with certain territories over others (Johnson and Toft 2014).

Although a considerable amount of the violence over land in Kenya is attributed to cyclical events such as elections and the politicization of ethnic groups, a brief overview of historical events shows that land questions have long dominated public debates in Kenya (Campbell et al. 2000; Boone 2012). The politics of the 1899 "Crown Land"-extended in 1902-for instance, contributed to the disruption of the initial land arrangements in occupied territories commonly known as the "highlands" (Veit 2011). At the core of the Crown Land policy, which was often revised to accommodate more 
settlers, was the declaration that all land belonged to the colonial state, thereby discrediting customary land rights and introducing individual freehold title as a legal means of land ownership (Berman 1990; Okoth-Ogendo 1989). And, as Klopp notes, "the result was that those loyal to the colonial government were rewarded and those involved in Mau Mau were punished with loss of their land" (Klopp 2000: 16).

The succession of several land registration schemes in the pre-independence period (e.g. the 1954 Swynnerton Plan, the 1959 Native Land Registration Ordonnance, and 1963 Registered Land Act) all paved the way to the Land Adjudication Act in 1968, five years after independence (Yamano and Deininger 2005). In a sense, "Kenya's latecolonial land-tenure reform was intended to presage agrarian revolution along preindustrial European lines... [which] began in central Kenya under the Swynnerton Plan in the 1950s [...] first undertaken with the advantage of confinement of much of Central Province's African population into fortified emergency villages established to contain the 1950s Mau Mau rebellion" (Haugerud 1989: 63). The same argument is advanced by Kanogo (1987) who notes that the shifts in land tenure regime during colonization saw the increase in the number of "squatters" around the so-called "white highlands" and subsequent rise of pressure groups such as the Mau Mau fighters (Kanogo 1987). Accordingly, these land registration processes "increased tenure security for many landowners... [and] created new forms of disputes, such as challenges over registered land and conflict over land sales" (Shipton 1988, cited in Yamano and Deininger 2005: 4).

However, this perspective is not shared by all. Some scholars, such as Camm (2012), have argued that the challenges of ethnicity, which often exacerbate land tensions in Kenya, were already in place before colonial occupation. In this view, colonialism simply heightened land conflicts, driving pre-existing tensions by changing land access rights. Meanwhile, other scholars have argued that Kenya's independence in 1963 only saw the end of "formal colonialism" as an active practice but not as an overall problem, while corruption ensued when colonial rule shifted into an authoritarian style political structure (Keller 2014). Another argument closely related to the former is the preservation of power among elites: believed to allow land conflicts to continue amongst communities, these elites were only interested in preserving their newfound political power (Boone 2012; Klaus 2017). Precisely, "following independence in 1963, president Kenyatta maintained rural control through a combination of clientelistic structures and a continuation of the colonial administrative system" (Funder and Mirani 2015: 90). Kenyatta's successor, President Moi, “intensifi[ed] irregular allocations of public land to well-connected individuals and land-buying companies" in areas such as Karura forest despite resistance from pressure groups (Klopp 2000: 8).

In such a context, the revival of the multi-party political system only added to the fragility of land governance in the post-colonial era, away from the colonial-rooted one-party system (Khadiagala 2010). The traumatic events that followed the 2007-2008 elections are a clear indication that conflict over land has deep root causes that require rethinking how land institutions (whether communal or national) have to approach land questions (Linke et al. 2018; Boone et al. 2019). This is because they have long lasting effects on current structures, whether social, political or economic. Along the same lines of argument, Peters (2009) observes that "the pervasive competition and conflict over land call into serious question the image of relatively open, negotiable and adaptive customary systems of landholding and land use and, 
instead, reveal processes of exclusion, deepening social divisions and class formation" (Ibid.: 270). This underscores the difficulty in balancing customary and national land policies. Further, the often-disputed borders between Kenya and its neighbours such as Uganda and Somalia add to the challenges that land institutions have to deal with in spite of the colonial structures and/or demarcations upon which they are grounded (Oduntan 2015).

\section{Environmental and/or Climate Change Explanations of Land Conflict}

Environmental concerns are also a leading explanation of conflicts over land in Kenya. For the most part, environmental narratives about land conflicts are found within the conservation literature (Agrawal 2005; Brown, Hammill and McLeman 2007). Increased struggles for water and food security due to uncertain climatic conditions form the basis upon which environmental explanations of land conflicts are grounded. In Tana River County, for instance, the mobile livelihoods of pastoralist communities such as the Orma are seen as clashing with the livelihood practices of agro-pastoralist groups such as Pokomo, particularly during drought and famine (Bond 2014).

Accordingly, climate-induced people mobility and wildlife migration have been shown to contribute to enhanced conflict between transhumant, sedentary and nomadic livelihood practices. Recent studies on the interconnections between climate change and land use conflict in Kenya show that rural areas with significant rainfall shortages are more prone to violence (Linke et al. 2018). Linking land conflict with both the demands of agriculture and resource shortages, such studies have argued that "while environmental change and shortages of rainfall represent a stress for many households' livelihoods, certain regulations may ameliorate these difficulties" (Ibid.: 1573). In essence, these studies demonstrate that struggles over limited resources, particularly land, are exacerbated by both environmental factors and unequal structure of property rights.

Furthermore, land conflicts in Kenya have also been attributed to migratory and mobility patterns, whether rural-rural or rural-urban, which alter the dynamics of existing struggles over limited resources such as land (Mwita 2017). While it is true that climate change is not the only reason behind migrations, it is also true that as populations migrate to other territories, overcrowding becomes a reality with the potential to heighten existing socio-economic tensions within and among populations (Abuodha 2002). In writing about migrations and the changing patterns of pastoral mobility in East Africa, van Baalen and Mobjörk write: "confronted by increasing resource scarcity, resource-dependent populations often respond by migrating to areas where resources are available or where there are alternative livelihoods, such as urban areas... [where] environmental change also affects the livelihoods and movements of permanent migrants, such as livestock herders, by upsetting the sustainability of their traditional mobility patterns" (van Baalen and Mobjörk 2018: 559).

Precisely, the authors show that "in the Turkana district in Kenya, both the frequency and intensity of livestock-related violence are higher in wetter areas on the plateaus and high rising ridges when the Turkana are the attackers" (Ibid.: 561). They also observe that "in the Lolita forest in southern Kenya, cooperation between neighbouring Maasai communities has become more difficult to maintain with the slow and continuous' in-migration by the Purko Maasai” (Ibid.: 560). Overall, environmental 
and/or climate change discourse on land conflict focuses on issues of mobility, migrations, and struggles over limited resources such as water and grazing pastures.

\section{Natural Resource Extraction and Unbalanced Rent Sharing}

Closely related to climatic and environmental explanations of land conflict in Kenya, there is growing literature focusing on resource extraction and unbalanced rent sharing (Abuya 2017; Abuodha and Hayombe 2006). At the core of these arguments is the delicate balance between who controls, uses, or benefits from the resources extracted from certain territories, often seen as belonging to particular groups. As Abuya puts it, "the major source of conflict is usually over who owns (and therefore controls) the land on which mining activity is taking place" (Abuya 2017: 593).

In addition to rent seeking and rent sharing narratives as possible explanations for conflict over land, there is also the question of displacement that is closely tied to natural resource extraction. For instance, studies by Abuodha (2002) on compensation programs offered to the residents of Kwale, living in the Titanium rich coastal strip of Kenya, showed that forced resettlement schemes in non-mineral areas increased conflicts between local residents. This is because the socio-economic opportunities and livelihood practices are tied to natural resource extraction.

On the flipside, Abuodha notes that, "whereas mining may result in positive socioeconomic benefits to societies and communities near mining areas, social ills and vices, including loss of cultural cohesion and interpersonal dynamics, breakdown of cultural norms and traditions, and increased crime and disease are some of the undesirable social impacts that can arise" (Abuodha 2002: 203). All of this contribute to the changing dynamics of conflict over land in Kenya. Further, the quest for natural resource rents for urban development and agricultural commercialization, particularly among a handful of political elites, has increased the value of land and subsequent "land grabs" (Klopp 2000). Apart from urban "land grabs" in Kenyan cities such as Nairobi and Mombasa, rural areas of the Rift valley, Central, and Coastal regions are also witnessing an increase in these irregular allocations of lands. Land grabbing has become a frequent occurrence in Kenya due to little or lack of documentation for land ownership by communities. Historically, the problems of land ownership are tied to the fact that "ethnic entrepreneurs and political brokers played a significant role in instigating violence" (Keller 2014: 122).

Recently, however, "the intensification of irregular allocations of public land to wellconnected individuals and land-buying companies in Kenya's "land grabbing mania" is a particularly revealing and underscrutinized case of deepening corruption" (Klopp 2000: 8). Land grabbing in Kenya has also been associated with the rise of urbanization and porous land ownership regulations (Lombard and Rakodi 2016). Location, affordability, and quick legal transaction are three important components for successful urban growth, however these are all impeded within the current land rules system, particularly in Nairobi (Lombard and Rakodi 2016). Further, large-scale landbuying or leasing by foreign governments such as "Qatar ha[ve] begun acquiring 40,000 hectares in Kenya's Tana River delta to grow fruit and vegetables, despite a drought that sees the UN feeding four million Kenyans" (Williams 2009: 1053). 


\section{Political Dynamics of Land Conflict} of land-related grievances by political elites and the struggles to control the state machinery, which, for the most part, oversees the institutions of land governance and property access (Boone 2011; Greiner 2013; Klopp 2000; Klaus 2017). The result of this is that whoever controls the state machinery has the ability to partially influence the opportunities associated with land ownership (Keller 2014; Khalif and Oba 2013; Williams 2009), including the organization of people's concept of territoriality through "spatial ordering" (Sikor and Lund 2009). This is because "the process of seeking authorizations for property claims also has the effect of granting authority to the authorizing politico-legal institution" (Ibid.: 1). For instance, following independence, "Kenyatta used the former settler land as patronage to solidify his support and build alliances, and many former loyalists became prominent in the new KANU government" (Klopp 2000: 16). This, in part, explains why the politics around land rights and land ownership have become a common theme in Kenya's electoral processes, as historically rooted grievances and claims over the need to recapture land in the "lost" territories often resurface (Keller 2014; Mwita 2017; Klaus 2017).

ing access to senior political leadership is, in this regard, seen as a potential means or authority to undo the perceived injustices surrounding historical land allocations and/or acquisitions because political leadership serves as "the 'contract' that links property and authority" (Sikor and Lund 2009: 1). Indeed, targeted killings and evictions in areas such as Rift Valley have been attributed to the politicization of historical grievances by political elites. The findings by the Akiwumi Report ${ }^{4}$ on "tribal" clashes in Kenya provides important details to this end. Put differently, "the process of seeking authorization for property claims also works to authorize the authorizers and, at the same time, institutions underpinning various claims of access-hence catering for particular constituencies-undermine rival claims to the same resources" (Sikor and Lund 2009: 1-2).

Although Kenya adopted a new Constitution in 2010, which provides the ground for the implementation of the National Land Policy through institutions such as the National Land Commission (NLA), increased politicization of these institutions means that they are likely to make politically motivated decisions. Yet, the 2007-2008 post-election violence is a stark reminder of the risks associated with the politicization of land ownership. It is to be noted that before 2010, Kenya did not have a comprehensive system for land laws, particularly those relating to women's land rights. Women, more so in rural areas, were more likely to be systematically excluded from family and patriarchal land ownership (Ministry of Lands 2009). Overall, the complex nature of land and/or property access paired with the political goals for land claims has already in the past incited violence and stokes its continuation.

\section{"Sons of the Soil" Narrative and Issues of Identity in Land Conflict}

In recent years, there has been a growing interest among scholars to examine the intricate relationship between identity and territorial affinity, and how they recursively interact to influence conflict over land (Lonsdale 2008; Horowitz and Klaus 
2018; Medard 2008; Dunn 2009; Gray 2011). In writing about what he calls the "sons of the soil" claims in Kenya, Lonsdale (2008) observes that:

To be 'sons of the soil' (it is always sons) is only one and, in terms of historical depth, not the most convincing means to make a claim on the Kenyan state. It tends to rest on recently acquired or ideologically constructed rights. In the 1920s white settlers, beneficiaries like the Sudanese of arbitrary state favour at the expense of others more native than they, resented being termed immigrants by the British government (Lonsdale 2008: 308). citizenship claims, and how they interact to generate conflict over land (Oduntan 2015). For some Kenyan communities, one cannot separate land from the people because of the dialectic and existential pull the two exert from one another. "Autochthony," as a local understanding of land conflict in Kenya, describes the close bond of citizens born in a certain geographic area, the same as their ancestors, and have a shared identity claim to the land (Kameri-Mbote and Kindiki 2008; Médard 2008). Territorial identity of certain populations, especially in rural agricultural lands, often revolve around ancestral claims, and such claims are more significant to such populations than any land laws (Keller 2014). The problem is that the claims of territorial identity rooted in ancestral claims create a sense of land entitlement or ownership and subsequent politicization of inter-group cohabitation, more so during election periods. Those who "do not belong" to the acclaimed territories therefore become vulnerable to the politics of eviction which the national and local elites incite.

The challenge of advancing the "autochthony" rationale over land ownership in Africa, particularly in Kenya, is that such claims shift depending on political context and perceived gains and losses. While "autochthony discourses appear to provide a sense of primal security and certainty" (Dunn 2009: 114-115), the sub-division of the already numerous ethnic groups in Kenya makes it difficult to honour such claims (Médard 2008; Akoth 2018). This illustrates that although "autochthony" may serve as a means to claim land ownership, the question of identity remains a deep-rooted barrier to the enactment of land policies that are inclusive and respectful of people's shifting sense of identity. This is because of the "ethnic appeals" that not only characterize sociopolitical landscape in Kenya, but also incentivize conflict over land.

Consistent with this perspective, scholars such as Horowitz and Klaus have observed that "appeals to ethnic grievances can encompass multiple logics, connecting to feelings of economic and political powerlessness stemming from the inability to secure land, alongside the belief that the victory of an ethnic patron will produce material benefits related to land, employment, or security" (Horowitz and Klaus 2018: 5). While the narratives of autochthony have increasingly become a common explanation of conflict over land in Kenya, other scholars have warned about its traction in African contexts. Precisely, scholars such as Dunn argue that "the growing multiplicity and contingency of identities available to persons in the contemporary world can produce a daunting sense of uncertainty about people, places, events and even cosmologies" (Dunn 2009: 121). 


\section{Main Actors in Kenya's Land Conflict}

underlying causes. Providing a detailed account of actors driving conflict over land in Kenya is therefore beyond the scope of this literature review. However, since land claims are tied to people's sense of security, livelihoods, identity, pride, etc., identifying and discussing the main actors driving such narratives is important. For the purposes of this review of literature, we have narrowed them into three broad categories: national actors, regional actors, and international actors. The rationale for this categorization is premised on the assumption that actor-relationship mapping is an important step towards communicative understanding of the complex dynamics of land questions in Kenya. This brings to focus the multidimensionality of land claims, and how actors' positions often intersect with perceived needs, opportunities, interests, and fears. In short, actor-relationship mapping draws from the conflict analysis perspective to understand how stakeholders in a given conflict interact communicatively to influence the process and/or outcome of conflict, including the areas of contestation (Grimm and Weiffen 2018).

\section{National Actors}

At the local level, we can identify state and non-state actors (NSAs). The state, as an actor in conflict, may exert (or seek to exert) control over its territories, including those that are led by agents who are uncollaborative towards state-led policies. This may take the form of land grabbing, and, as argued by Klopp (2000: 22), "Kenya's 'land grabbing mania' correctly illustrates how powerful actors who have a stake in maintaining patrimonial control will find alternative sources of patronage assets when confronted with constraints on traditional sources such as aid." Depending on how state efforts are received in concerned areas, it may choose to use coercive measures and/or one-sided state violence against groups or individuals who impede its initiatives. As witnessed during Kenyatta's and Moi's presidencies, the manipulation of land rights and irregular allocation of public lands were not only used for political gains; they were also used for coercive purposes (Greiner 2013; Funder and Marani 2015).

The problem with such an approach is that the changing dynamics of conflict over land in Kenya have also seen an increase in NSAs who take active roles in shaping the direction of land conflict. This is probably why recent studies emphasize the need to include non-state actors in peacebuilding processes. For instance, when Moi's government started irregular allocation of Nairobi's Karura forest in the 1990s, NSAs such as the National Council of NGOs of Kenya launched several anti-land grabbing awareness campaigns under the "Operation Firimbi" (Klopp 2000). Equally, "the National Council of Churches of Kenya, the Law Society of Kenya, the Architectural Association of Kenya, the Kenya (No. N) Human Rights Commission among many other groups joined a clamor of voices demanding to know to whom the forest had been allocated" (Ibid.: 13). This shows the extent to which NSAs can put pressure on the government, while, at the same time sparking protests and violence over irregular land allocations. According to Hofmann and Scheckener, two dominant reasons explain why NSAs, particularly armed groups, have increasingly been integrated into the overall 
peacebuilding strategy: "on the one hand, they are often perceived as responsible for violence against unarmed civilians in breach of international humanitarian law, as well as for the establishment of criminal and informal economies. On the other hand, they are often the expression of social problems because they see themselves as representatives of distinct interests and may build on broad support within communities" (Hofmann and Scheckener 2001: 2).

Admittedly, armed NSAs have been blamed for perpetrating land-based violence in areas such as Rift Valley and Tana River, particularly during electoral periods leading to the forced displacement of persons (Boone 2012; Keller 2014; Mwita 2017). Whereas some of the NSAs may act autonomously, studies also show that they can be instrumentalized by conflict entrepreneurs, politicians, and political parties to carry out acts of violence (Rohwerder 2015; van Leeuwen and van Der Haar 2016). The 2007-2008 post-election violence in Kenya, particularly in Rift Valley, was blamed in part on the instrumentalization and mobilization of various groups by conflict sponsors and/or entrepreneurs to carry out targeted attacks or retaliatory attacks against particular groups (Schilling, Opiyo and Schefran 2012; Kameri-Mbote and Kindiki 2008). Indeed, ethnic pressures caused by the 2007-2008 electoral violence and land claims have influenced the political structure over the last decade, ultimately leading to the doubling of political officials, which has convoluted policy implementation processes (Adam, Collier and Ndung'u 2011). Overall, while national actors have increasingly become important influencers of land policies, it is to be noted that, "in Kenya, until recently, the state has been the principal actor in the policy-making arena... [and] the executive has traditionally dominated both the processes and the institutional framework for policy making" (ECDMP 2002).

\section{Regional Actors}

Regional actors have also played an important role in underpinning land narratives in Kenya. Cross-border conflicts between Kenya and its neighbouring countries such as Somalia, Ethiopia, and Uganda have been on the rise in the past couple of decades (Okumu 2010). For some, cross-border conflicts in East Africa are fuelled by the changing regional economy and ambitious large-scale development programs that have increased public-private partnerships (Mosley and Watson 2016). At the core of these developments is the issue of cross-border security, with communities on either side of the border becoming vulnerable to inter-group conflicts. The construction of dams and other mega-infrastructure projects (e.g. LAPSSET program) have, for instance, led to forced migration of communities living along the Kenya-Ethiopia borders and their contestation, as some of these "visions" are not supported by the communities affected (Mosley and Watson 2016).

Realizing the problems surrounding land questions in the region, regional organizations such as the African Union (AU) have tried to propose a "unified" vision of land rights across the African continent (AU, 2010). Among others, AU's proposed framework "offer[s] a basis for commitment by African member states to the formulation and operationalisation of sound land policies as a basis for sustainable human development that includes assuring social stability, maintaining economic growth and alleviating poverty and protecting natural resources from degradation and pollution" (AU 2010: 2). This comes with the realization that the land question is not 
only a hindrance to development and cooperation within and across regional borders; it contributes to the struggles over limited natural resources and violence between groups.

Consistent with this perspective, Kumssa et al. (2014) remind us that "there are presently over one million registered Somali refugees throughout East Africa with more than $50 \%$ of these refugees being located in Kenya... [and that such an] influx of refugees has stressed local resources within Kenya and requires careful negotiation between host community residents and refugees" (Kumssa et al. 2014: 145). Moreover, the ongoing maritime dispute between Kenya and Somalia-currently referred at the International Court of Justice (ICJ)-indicates the delicate balance between regional cooperation and the advancement of national interests around natural resource access and use (Chan, 2018). Mpeketoni region on the coast have also been marred by conflict over land, which revolves around the "government's long history of resettling displaced and landless people from other areas to land belonging to indigenous people"5. Further, the dispute between Kenya and Uganda over Migingo Island-on Lake Victoria-is another indication of increasing conflict over territory between Kenya and its neighbouring countries (Shaka 2013). In addition to boundary disputes, regional party states also face similar land questions within their borders with limited or no political will to solve historically rooted land issues (AU 2010).

Since intervention is a negotiated effort, interests often supersede political will, particularly when such efforts revolve around land tenure in war-torn zones. As Unruh reminds us, "war-torn land tenure situations are unique settings in their combination of a weakened and chaotic formal (statutory) system, vigorous but very fluid informal tenure activity, along with the presence of political demands regarding land, and international actors that have a large interest and influence in the success of any improvement or recovery" (Unruh 2011: 89). This is particularly the case for Kenya, where securing land rights in areas such as Tana River and Garissa remains a daunting challenge for the state. Cattle raiding practices have resulted in protracted conflict between pastoral and agro-pastoral communities living along Kenya-Ethiopia and Kenya-Somalia borders (Greiner 2013; Khalif and Oba 2013; Schilling, Opiyo, and Scheffran 2012; Witsenburg and Adano 2009). In writing about "guns, land and votes" in northern Kenya, scholars such as Greiner have argued that, while cattle rustling can be attributed to climatic transformations of the drylands, such "approaches depoliticize raiding and tend to ignore important changes within pastoralist communities and how they relate to political developments in Kenya at large" (Greiner 2013: 112). In short, the politics around territoriality have gradually become an organized crime resulting in the armament of young men and boys for political gains.

\section{International Actors}

The role of international actors in influencing the direction of land conflicts in Kenya has taken many forms, ranging from foreign governments leasing large tracts of land to international pressure groups and aid agencies seeking ways to prevent irregular allocation of public lands such as forests. Precisely, international actors influencing land narratives in Kenya include, but are not limited to, international NGOs, UN agencies (e.g. UNEP and UN-Habitat), international land-buying and land-leasing companies, humanitarian organizations, and donor agencies. 
51 In writing about the "grabbing" of Karura forest that began during Moi's presidency and the "mild reaction" it received from the international community, Klopp noted that "public land appears to be largely unfettered by international conditionalities or scrutiny. Hence, it is a useful asset in light of increased restrictions intended to limit forms of corruption more familiar to international observers" (Klopp 2000: 15). Therefore, even though international actors such IMF and World Bank may exert pressure on governments through the threat of sanction, allocation of public land by national government often draws minimal international reaction.

The Kenya-Qatar deal over the 40,000 hectares leasing in Kenya's River Tana Delta is one example of how international actors (e.g. foreign governments) are becoming increasingly involved in changing the dynamics of land access rights in Kenya (Williams 2009). With rising pressures from international actors such as OCHA and UNHabitat advocating for the rights of internally displaced persons (IDPs) and the growing push to increase food security in the country, such land deals are often met with mixed feelings. In fact, as Kamungi notes, "in 2012, clashes over water sources and pastures in the Tana Delta and parts of Northern Kenya, cattle-rustling and localized political violence among pastoralist communities across Kenya's North left scores dead and over 118,000 displaced" (Kamungi 2013: 4).

53 Overall, coordinating national, regional, and international structures and/or institutions of land access rights remains a major challenge. In the case of IDPs resettlement programs, for instance, "the Ministry of Local Government, which is responsible for cities, municipalities, town and county councils, is not directly involved in the management of IDPs given that the Ministry of State for Special Programs (MOSSP) is the focal point for all IDP matters" (Kamungi 2013: 27). Navigating these hierarchies represents a tall order for land institutions, whether at the local, regional or international levels. This is exacerbated by land-buying companies, as they increase land value, land grabbing, and struggles for land ownership (Boone 2012; Williams 2009). This is because they inform migration patterns, sometimes forced, to create room for large-scale agricultural production or mineral extraction purposes.

\section{Conclusion}

Over the past decade, land questions in Kenya have not only become a policy concern given their central role in inter-group conflicts, but are also a topic of particular interest to scholars on Africa. This comprehensive literature review identified five dominant explanations or agencies in conflict over land in Kenya, as advanced within academic and policy circles: colonial legacy, environmental concerns, natural resource extraction, political dynamics, and "sons of the soil" narratives as the dominant lines of argument used to characterize agency in land conflict in Kenya. Colonial legacy underscores historically rooted claims of land possession and dispossession; environmental concerns underpin the role of climate change in people and animal mobility, which creates pressure and tension or conflict over land between communities; political factors revolve around the control and governance of land for electoral gains and the capture of power; natural resource extraction problems highlight unbalanced rent sharing practices; and the "sons of the soil" discourse centers on people's sense of belonging as they relate to land ownership. 

communicative interactions between national, regional, and international actors shape land questions in Kenya, and in Africa more generally. The actors function as both the source and/or driver of land conflict, as well as interveners in "solving" land questions. National actors have been categorized into two broad groups: the state and non-state actors such as civil society organizations and other "neo-customary authorities" such as Council of Elders. Regional actors include, but are not limited to member states, countries and regional organizations such as the AU. Finally, international actors include institutions of global governance (e.g. UN), private actors (e.g. international companies/groups), and international NGOs. problems in Kenya, there is relatively very little work on the roles of regional and international actors in shaping conflict over land in Kenya. The existing literature centers on national actors, particularly the state, land institutions, and politicians. Yet, regional actors (e.g. AU) and international actors (e.g. ICJ) increasingly take active part in the politics of land in Kenya, including boundary disputes. The roles of regional and international actors may require further theoretical and empirical exploration.

Finally, the framing of land questions in the existing literature points to a strong tilt toward "fixing" land institutions as a means to solve Kenya's land conflict puzzle. Yet, as Boone et al. (2019) observes, reducing land conflict in Kenya to problems of institutional regulations still leaves a lot to be desired. Overall, by identifying and discussing the common areas around which land questions are hinged, this literature review offers a means to sort through the fragmented research on land conflicts in Kenya. Specifically, it offers a window into understanding "how particular land-related conflicts are performed, stimulated, interpreted and used by different actors at different levels, both for private gain as well as for ideological reasons" (van Leeuwen and van Der Haar 2016: 102).

Literature review for this article benefited from the Social Sciences and Humanities Research Council (SSHRC) grant, under Insight Development Grants.

\section{BIBLIOGRAPHY}

Abuodha, J.Z. and P.O. Hayombe. 2006. "Protracted Environmental Issues on a Proposed Titanium Minerals Development in Kenya's South Coast.” Marine Georesources and Geotechnology 24 (2): 6375. http://dx.doi.org/10.1080/10641190600704251.

Abuodha, J.Z. 2002. "Environmental Impact Assessment of the Proposed Titanium Mining Project in Kwale District, Kenya.” Marine Georesources and Geotechnology 20 (3): 199-207. https://doi.org/ $10.1080 / 03608860290051895$.

Abuya, W.O. 2017. "Resource Conflict in Kenya's Titanium Mining Industry: Ethno-ecology and the Redefinition of Ownership, Control, and Compensation." Development Southern Africa 34 (5): 593-606. https://doi.org/10.1080/0376835X.2017.1351869. 
Adam, C., P. Collier and N. Ndung'u, eds. 2011. Kenya: Policies for Prosperity. New York: Oxford University Press.

African Union (AU) 2010. Land Policy in Africa: A Framework to Strengthen Land Rights, Enhance Productivity and Secure Livelihoods. Addis Ababa: AUC-ECA-AfDB. [Archive]

Agrawal, A. 2005. Environmentality: Technologies of Government and the Making of Subjects. Durham, NC and London: Duke University Press.

Akoth, S.O. 2018. "Land as Culture: Discourse and Narratives of Land Claims in Postcolonial Kenya.” African Studies 77 (2): 189-203. https://doi.org/10.1080/00020184.2018.1452854.

Alden, C., and W. Anseeuw. 2010. The Struggle over Land in Africa: Conflicts, Politics and Change. Cape Town, South Africa: HSRC Press.

Ani, C. 2013. "Managing Climate Change in Africa: Challenges To Traditional Knowledge Systems And Human Values." Fourth World Journal 12 (1): 29-44.

Austin, G. 2010. “African Economic Development and Colonial Legacies.” Revue Internationale de Politique de Développement 1 (1): 11-32. http://doi.org/10.4000/poldev.78.

Bates, R.H. 2005. Beyond the Miracle of the Market: The Political Economy of Agrarian Development in Kenya. Cambridge, UK: Cambridge University Press.

Baynham-Herd, Z. et al. 2018. "Conservation Conflicts: Behavioural Threats, Frames, and Intervention Recommendations." Biological Conservation 222 (C): 180-188. https://doi.org/ 10.1016/j.biocon.2018.04.012.

Berman, B. 1990. Control and Crisis in Colonial Kenya: The Dialectic of Domination. London: James Currey.

Besley, T., and M. Reynal-Querol. 2014. "The Legacy of Historical Conflict: Evidence from Africa." American Political Science Review 108 (2): 319-336. https://doi.org/10.1017/S0003055414000161.

Blanton, R., T.D. Mason, and B. Athow. 2001. "Colonial Style and Post-Colonial Ethnic Conflict in Africa." Journal of Peace Research 38 (4): 473-491. https://doi.org/10.1177/0022343301038004005.

Boone, C. 1990. "The Making of a Rentier Class: Wealth Accumulation and Political Control in Senegal." The Journal of Development Studies 26 (3): 425-449. https://doi.org/ $10.1080 / 00220389008422163$.

Boone, C. 2011. "Politically Allocated Land Rights and the Geography of Electoral Violence: The Case of Kenya in the 1990s." Comparative Political Studies 44 (10): 1311-1342. https://doi.org/ $10.1177 / 0010414011407465$.

Boone, C. 2012. "Land Conflict and Distributive Politics in Kenya." African Studies Review 55 (1): 75103. https://doi.org/10.1353/arw.2012.0010.

Boone, C. 2017. "Sons of the Soil Conflict in Africa: Institutional Determinants of Ethnic Conflict Over Land.” World Development 96: 276-293. http://doi.org/10.1016/j.worlddev.2017.03.012.

Boone, C. et al. 2019. "Land Law Reforms in Kenya: Devolution, Veto Players, and the Limits of an Institutional Fix.” African Affairs 118 (471): 215-237. https://doi.org/10.1093/afraf/ady053.

Bond, J. 2014. "A Holistic Approach to Natural Resource Conflict: The Case of Laikipia County, Kenya.” Journal of Rural Studies 34 (2014): 117-127. https://doi.org/10.1016/j.jrurstud.2014.01.008. Brown, O., A. Hammill, and R. McLeman. 2007. "Climate Change as the 'New' Security Threat: Implications for Africa." International Affairs 83 (6): 1141-1154. [Archive] 
Camm, M. 2012. “A Relative Peace: Ethnic Land Conflict in Post-war Ituri District, Democratic Republic of the Congo." PhD Diss., University of North Carolina at Chapel Hill. https://doi.org/ $10.17615 /$ qzfv-by12.

Campbell, D.J. et. al. 2000. "Land Use Conflict in S.E. Kajiado District, Kenya." Land Use Policy 17 (4): 337-348. http://dx.doi.org/10.1016/S0264-8377(00)00038-7.

Carmignani, F., and A. Chowdhury. 2010. Why are Natural Resources a Curse in Africa, But Not Elsewhere? School of Economics, University of Queensland.

Chan, K.C. 2018. "The ICJ's Judgement in Somalia v. Kenya and Its Implications for the Law of the Sea." Utrecht Journal of International and European Law 34 (2): 195-204. http://doi.org/10.5334/ujiel. 450.

Deininger, K., T. Hilhorst, and V. Songwe. 2014. "Identifying and Addressing Land Governance constrayints to Support Intensification and Land Market Operation: Evidence from 10 African countries." Food Policy 48: 76-87. https://doi.org/10.1016/j.foodpol.2014.03.003.

Dell'Angelo, J. et al. 2017. "The Tragedy of the Grabbed Commons: Coercion and Dispossession in the Global Land Rush." World Development 92: 1-12. https://doi.org/10.1016/j.worlddev.

2016.11.005.

East Africa Living Encyclopedia. (n.d.). Retrieved January 1, 2019, from https:// www.africa.upenn.edu/NEH/kethnic.htm

ECDPM 2002. "Institutional Analysis of Non-State Actors in Kenya." Report presented to DFID, retrieved from http://gsdrc.org/docs/open/po35.pdf [archive].

Environmental Justice Foundation. 2014. The Gathering Storm Climate Change, Security and Conflict. United Kingdom.

Fenske, J. 2011. "Land Tenure and Investment Incentives: Evidence from West Africa." Journal of Development Economics 95 (2): 137-156. https://doi.org/10.1016/j.jdeveco.2010.05.001.

Frynas, J.G., G. Wood, and T. Hinks. 2017. "The Resource Curse without Natural Resources: Expectations of Resource Booms and their Impact.” African Affairs 116 (463): 233-260. https:// doi.org/10.1093/afraf/adx001.

Funder, M. and M. Marani. 2015. "Local Bureaucrats as Bricoleurs. The Everyday Implementation Practices of County Environment Officers in Rural Kenya." International Journal of the Commons 9 (1): 87-106. http://doi.org/10.18352/ijc.526.

Greiner, C. 2013. "Guns, Land, and Votes: Cattle Rustling and the Politics of Boundary (Re)making in Northern Kenya." African Affairs 112 (447): 216-237. https://doi.org/10.1093/afraf/adt003.

Grimm, S. and B. Weiffen. 2018. "Domestic Elites and External Actors in Post-Conflict Democratisation: Mapping Interactions and Their Impact." Conflict, Security \& Development 18 (4): 257-82. https://doi.org/10.1080/14678802.2018.1483556.

Gwaleba, M.J., and F. Masum. 2018. "Participation of Informal Settlers in Participatory Land Use Planning Project in Pursuit of Tenure Security." Urban Forum 29 (2): 169-184. https://doi.org/ 10.1007/s12132-018-9330-y.

Haugerud, A. 1989. "The Consequences of Land Tenure Reform among Smallholders in the Kenya Highlands." Rural Africana 15-16: 65-89.

Hofmann, C. and U. Schneckener. 2011. "Engaging Non-State Armed Actors in State- and Peacebuilding: Options and Strategies." International Review of the Red Cross 93 (883): 603-621. https://doi.org/10.1017/S1816383112000148. 
Horowitz, J. and K. Klaus. 2018. "Can Politicians Exploit Ethnic Grievances? An Experimental Study of Land Appeals in Kenya" Political Behavior: 1-24. https://doi.org/10.1007/

s11109-018-9485-1.

Janus, T. 2012. "Natural Resource Extraction and Civil Conflict." Journal of Development Economics 97 (1): 24-31. https://doi.org/10.1016/j.jdeveco.2011.01.006.

Johnson, D.P., and M.D. Toft. 2014. "Grounds for War: The Evolution of Territorial Conflict." International Security 38 (3): 7-38. https://doi.org/10.1162/ISEC_a_00149.

Kalabamu, F.T. 2019. "Land Tenure Reforms and Persistence of Land Conflicts in Sub-Saharan Africa-The Case of Botswana." Land Use Policy 81: 337-345. https://doi.org/10.1016/j.landusepol. 2018.11.002.

Kameri-Mbote, P., and K. Kindiki. 2008. "Trouble in Eden: How and Why Unresolved Land Issues Landed 'Peaceful Kenya' in Trouble in 2008." Forum for Development Studies 35 (2): 167-193. http:// doi.org/10.1080/08039410.2008.9666408.

Kamungi, P. 2013. Municipalities and IDPs Outside of Camps: The Case of Kenyas' 'Integrated Displaced Persons.' Brookings Institution-London School for Economics.

Kanogo, T. 1987. Squatters and the Roots of Mau Mau: 1905-63. Eastern African Studies. Athens: Ohio University Press.

Kanyinga, K. 1998. "Politics and Struggles for Access to Land: "Grants from Above" and "Squatters" in Coastal Kenya." European Journal of Development Research 10: 50-70.

Keller, E. 2014. Identity, Citizenship, and Political Conflict in Africa. Indiana University Press.

Khadiagala, G.M. 2010. "Political Movements and Coalition Politics in Kenya: Entrenching Ethnicity.” South African Journal of International Affairs 17 (1): 65-84. https://doi.org/ $10.1080 / 10220461003763858$.

Khalif, Z.K., and G. Oba. 2013. “'Gaafa Dhaabaa - the Period of Stop': Narrating Impacts of Shifta Insurgency on Pastoral Economy in Northern Kenya, C. 1963 to 2007." Pastoralism: Research, Policy and Practice 3 (14): 1-20. https://doi.org/10.1186/2041-7136-3-14.

Klaus, K. 2017. "Contentious Land Narratives and the Nonescalation of Election Violence: Evidence from Kenya's Coast Region." African Studies Review 60 (2): 51-72. https://doi.org/ 10.1017/asr.2017.2.

Klopp, J.M. 2000. "Pilfering the Public: The Problem of Land Grabbing in Contemporary Kenya." Africa Today 47 (1): 7-26. https://www.jstor.org/stable/4187305.

Kumssa, A. 2014. "Conflict and Migration: The Case of Somali Refugees in Northeastern Kenya." Global Social Welfare 1: 145-156. https://doi.org/10.1007/s40609-014-0006-9.

Linke, et al. 2018. "Drought, Local Institutional Contexts, and Support for Violence in Kenya." Journal of Conflict Resolution 62 (7): 1544-1578. https://doi.org/10.1177/0022002717698018.

Lombard, M., and C. Rakodi. 2016. "Urban Land Conflict in the Global South: Towards an Analytical Framework.” Urban Studies 53 (13): 2683-2699. https://doi.org/ 10.1177/0042098016659616.

Lonsdale, J. 2008. "Soil, Work, Civilisation, and Citizenship in Kenya." Journal of Eastern African Studies 2 (2): 305-314. https://doi.org/10.1080/17531050802058450.

Médard, C. 1996. "Les conflits 'ethniques' au Kenya: Une question de votes ou de terres?" ['Ethnic' Conflicts in Kenya: A Question of Votes, or of Land?] Afrique contemporaine 180 (4): 62-74. 
Mbah, E. 2016. Global Africa: Environment and Identity Politics in Colonial Africa: Fulani Migrations and Land Conflict. London, Taylor \& Francis.

Ministry of Lands 2009. "Sessional Paper No. 3 of 2009 on National Land Policy." Retrieved https://landportal.org/library/resources/lex-faoc163862/national-land-policy-sessional-paperno-3-2009 [archive].

Mitchell, M.I. 2018. "Migration, Sons of the Soil Conflict, and International Relations." International Area Studies Review 21 (1): 51-67. https://doi.org/10.1177/2233865917745417.

Mosley, J. and E.E. Watson. 2016. "Frontier Transformations: Development Visions, Spaces and Processes in Northern Kenya and Southern Ethiopia." Journal of Eastern African Studies 10 (3): 452-475. https://doi.org/10.1080/17531055.2016.1266199.

Mwita, J. 2017. "Ethnic Land Conflict a Constant Struggle in Kenya: A Critical inquest on the role played by the Methodist church in Meru County, Kenya." MA Diss., Norwegian School of Theology. http://hdl.handle.net/11250/2447750.

Ndung'u Report. 2004. "Report of the Commission of Inquiry into Illegal/Irregular Allocation of Land.” Nairobi: Government Printers.

Nuhu, S. 2019. "Peri-Urban Land Governance in Developing Countries: Understanding the Role, Interaction and Power Relation Among Actors in Tanzania." Urban Forum 30 (1): 1-16. https:// doi.org/10.1007/s12132-018-9339-2.

Obala, L.M., and M. Mattingly. 2014. "Ethnicity, Corruption and Violence in Urban Land Conflict in Kenya." Urban Studies 51 (13): 2735-2751. https://doi.org/10.1177/0042098013513650.

Oduntan, G. 2015. International Law and Boundary Disputes in Africa. London and New York: Routledge.

Okoth-Ogendo, H.W.O. 1989. "Some Issues of Theory in the Study of Tenure Relations in African Agriculture." Africa: Journal of the International African Institute 59 (1): 1-16. https://doi.org/ $10.2307 / 1160760$.

Okoth-Ogendo, H.W.O. 2002. "The Tragic African Commons: A Century of Expropriation, Suppression and Subversion." University of Nairobi Law Journal 12003 (1): 107-117. http:// erepository.uonbi.ac.ke:8080/xmlui/handle/123456789/35724.

Okumu, W. 2010. "Resources and Border Disputes in Eastern Africa." Journal of Eastern African Studies 4 (2): 279-297. https://doi.org/10.1080/17531055.2010.487338.

Onoma, A.K. 2010. "The Contradictory Potential of Institutions: The Rise and Decline of Land Documentation in Kenya." In Explaining Institutional Change: Ambiguity, Agency, and Power, eds. J. Mahoney and K. Thelen. Cambridge, UK: Cambridge University Press.

Oucho, J.O. 2002. Undercurrents of Ethnic Conflict in Kenya. Leiden, Netherlands: Brill.

Ovadia, J.S. 2013. "The Reinvention of Elite Accumulation in the Angolan Oil Sector: Emergent Capitalism in a Rentier Economy." Cadernos de Estudos Africanos (25): 33-63. http://doi.org/ 10.4000/cea.839.

Peters, P. 2004. "Inequality and Social Conflict over Land in Africa." Journal of Agrarian Change 4 (3), 269-314. https://doi.org/10.1111/j.1471-0366.2004.00080.x.

Posner, S., and C. Cvitanovic. 2019. "Evaluating the Impacts of Boundary-spanning Activities at the Interface of Environmental Science and Policy." Environmental Science and Policy 92: 141-151. https://doi.org/10.1016/j.envsci.2018.11.006. 
Pritchard, M.F. 2016. "Contesting Land Rights in a Post-conflict Environment: Tenure Reform and Dispute Resolution in the Centre-West Region of Côte d'Ivoire.” Land Use Policy 54: 264-275. https://doi.org/10.1016/j.landusepol.2016.02.022.

Redpath, S.M. et al. 2013. "Understanding and Managing Conservation Conflicts." Trends in Ecology and Evolution 28 (2): 100-109. https://doi.org/10.1016/j.tree.2012.08.021.

Rigon, A. 2014. "Building Local Governance: Participation and Elite Capture in Slum-upgrading in Kenya." Development and Change 45 (2): 257-283. https://doi.org/10.1111/dech.12078.

Rohwerder B. 2015. Conflict Analysis of Kenya. Birmingham. UK: GSDRC, University of Birmingham.

Rutherford, B. 2017. "Land Governance and Land Deals in Africa: Opportunities and Challenges in Advancing Community Rights." The Journal of Sustainable Development Law and Policy 8 (1): 235-258. http://dx.doi.org/10.4314/jsdlp.v8i1.10.

Schilling, J., F. Opiyo, and J. Scheffran. 2012. "Raiding Pastoral Livelihoods: Motives and Effects of Violent Conflict in North-eastern Kenya.” Pastoralism 2 (25): 1-16. https://doi.org/ 10.1186/2041-7136-2-25.

Scoones, I. et. al. 2019. "Narratives of Scarcity: Framing the Global Land Rush." Geoforum 101: 231241. https://doi.org/10.1016/j.geoforum.2018.06.006.

Shaka, J. 2013. "Migingo Island: Kenya or Uganda Territory?" Journal of Conflictology 4 (2): 34-37. http://dx.doi.org/10.7238/joc.v4i2.1886.

Sikor, T. and C. Lund. 2009. "Access to Property: A Question of Power and Authority." Development and Change 40 (1): 1-22. https://doi.org/10.1111/j.1467-7660.2009.01503.x.

Unruh, J. 2011. "Land Rights and Peacebuilding: Challenges and Responses." International Journal of Peace Studies 15: 89-125. https://www.jstor.org/stable/41853008.

van Baalen, S. and M. Mobjörk. 2018. "Climate Change and Violent Conflict in East Africa: Integrating Qualitative and Quantitative Research to Probe the Mechanisms." International Studies Review 20 (4): 547-575. https://doi.org/10.1093/isr/vix043.

Van Leeuwen, M. and G. Van der Haar. 2016. "Theorizing the Land-violent Conflict Nexus.” World Development 78: 94-104. https://doi.org/10.1016/j.worlddev.2015.10.011 [Repec].

Veit, P. 2011. "History of Land Conflicts in Kenya. Policy Brief by Focus on Land." https://doi.org/ $10.21955 /$ gatesopenres.1115885.1

Vincent, K. et al. 2018. "What Can Climate Services Learn from Theory and Practice of Coproduction?” Climate Services 12: 48-58. https://doi.org/10.1016/j.cliser.2018.11.001.

Wallensteen, P. 2013. Peace Research: Theory and Practice. London: Routledge.

Wamicha, W.N., and J.I. Mwanje. 2000. Environmental Management in Kenya: Have the National Conservation Plans Worked? Addis Ababa: Organization for Social Science Research in Eastern and Southern Africa [archive].

Watson, A. 2019. “'Home' in Peace and Conflict Studies: A Site of Resistance and of Reform." Peace and Conflict Studies 26 (1): 1-20 [archive].

Williams, N. 2009. “Alarm Bells over Africa Land Deals.” Current Biology 19 (23): 1053-1054. https://doi.org/10.1016/j.cub.2009.11.023.

Witsenburg, K. and W.R. Adano. 2009. "Of Rains and Raids: Violent Livestock Raiding in Northern Kenya.” Civil Wars 11 (4): 514-538. https://doi.org/10.1080/13698240903403915. 
Yamano, T. and K. Deininger. 2005. "Land Conflicts in Kenya: Causes, Impacts, and Resolutions." FASID Discussion Paper 2005-12-002. https://landportal.org/library/resources/land-conflictskenya-causes-impacts-and-resolutions [archive].

\section{NOTES}

1. "Land grab" is broadly understood as a form of corruption involving irregular allocation of public lands (see Klopp 2000).

2. Okoth-Ogendo defines the Commons as "ontologically organized land and associated resources available exclusively to specific communities, lineages or families operating as corporate entities... [and that] as a general rule, this is the manner in which agrarian resources in Africa were, and largely continue to be organized" (Okoth-Ogendo 2002: 107).

3. During colonization, a series of ordinances targeting land use patterns were enacted by the Colonial office to allow for the appropriation of lands for European settlement and for large-scale farming/agriculture by British settlers. Crown Land Ordinances (1902, 1915 and 1926) brought all lands under the authority of the Colonial office, allowing for the protection and delimitation of the Highlands for the pre-eminent European settlement. Access to or transfers of these lands were overseen by the colonial governor through the European Highland policy. Trust lands, on the other hand, were established by the colonial government for exclusive use of Africans with no guarantee in terms of security of tenure. This followed the declaration, by the colonial government, that all lands were under the authority of the Colonial office and the Queen of England. For a detailed discussion of these policies, see the authors cited.

4. See the report by the 1999 Judicial Commission of Inquiry into Tribal Clashes in Kenya https://digitalcommons.law.seattleu.edu/tjrc-gov/ [archive].

5. See International Displacement Monitoring Centre (IDMC) article, "Why Unresolved Land Issues Lay at the Heart of Displacement in Kenya's Coast Region." July 2014. http://www.internal-displacement.org/expert-opinion/why-unresolved-land-issueslay-at-the-heart-of-displacement-in-kenyas-coast-region [archive].

\section{ABSTRACTS}

Land governance continues to be a topic of high interest within policy and academic circles. The manner in which land institutions should (or should not) go about reforming national land policies has been a highly contested topic given the complex and multilayered nature of landrelated conflicts. The purpose of this literature review is to identify and discuss how, why, and by whom land conflicts are mobilized to generate tension, conflict, and violence over land in Kenya. The article argues that, in addition to "global land rush" narratives, the structure of politics is a key organizing element of land conflict in Kenya. This is because politics define the kinds of relationships people have with land, including the institutions that prescribe, manage, and 
oversee land rights. This literature review contributes more broadly to address land conflict and ethno-political violence in Kenya.

INDEX

Keywords: land conflict, land rules, land reforms, land institutions, property rights, boundary disputes

Geographical index: Kenya

\section{AUTHORS}

\section{PHILIP ONGUNY}

Philip Onguny is an Assistant Professor in the School of Conflict Studies at Saint Paul University in Ottawa. His research revolves around ethno-political violence in sub-Saharan Africa and the role of media in conflict transformation and peacebuilding. He is the co-editor of Lutte contre le terrorisme en Afrique: Acte de bienveillance ou prétexte géostratégique published by the University of Montreal Press.Saint Paul University, School of Conflict Studies. 223 Main Street, Ottawa, ON K1S 1C4.

\section{TAYLOR GILLIES}

Taylor Gillies holds an MA in Conflict Studies from Saint Paul University in Ottawa.Saint Paul University, School of Conflict Studies. 223 Main Street, Ottawa, ON K1S 1C4. 